\title{
The Effect of Golden Sea Cucumber (Stichopus hermanii) Extracts to Serum LDL Cholesterol level as a Result of Insulin Resistence
}

\author{
Herin Setianingsih ${ }^{*}$, Fatimasari Suryanto Putri 2, Wahyu Prasasti Mutiadesi 1, \\ Erlina Yatnasari ${ }^{3}$ \\ ${ }^{1}$ Anatomy, Biomedicine, Faculty Medicine of Universitas Hang Tuah, Surabaya, Indonesia \\ 2 Faculty Medicine of Universitas Hang Tuah, Surabaya, Indonesia \\ 3 Parasitology, Faculty Medicine of Universitas Hang Tuah, Surabaya, Indonesia
}

Article history:

Submission February 2020

Revised April 2020

Accepted April 2020

*Corresponding author:

E-mail:

herinpurwanto22@gmail.com

\begin{abstract}
Diabetes mellitus is a metabolic disease characterized by conditions of hyperglycemia as a result of abnormalities in the secretion of the insulin hormone, the work of the insulin hormone, or both. Metabolic disorders caused by diabetes cause lipolysis to increase, thereby increasing the level of VLDL, which will be converted to LDL. LDL disorders are the effects of insulin resistance. Streptozotocin (STZ) can increase serum LDL cholesterol serum levels due to the mechanism of ROS formation. Golden sea cucumber act as anti-hyperlipidemic because they contain EPA-DHA, saponins, and flavonoids. The purpose of these studies was to determine the effect of Golden sea cucumber act as anti-hyperlipidemic. Experimental laboratory research was done using the post-test only control group design method. Using simple random sampling with 25 white male Wistar rats divided into five groups, all rats were given standard feeding. Group 1 without STZ induced, group 2-5 were induced STZ first, and then group 3-5 were given golden sea cucumber extract for 21 days with dose $4.25 \mathrm{mg} / \mathrm{kg} \mathrm{BW}, 8.5 \mathrm{mg} / \mathrm{kg} \mathrm{BW}, 12.75 \mathrm{mg} / \mathrm{kg} \mathrm{BW}$, per day respectively. At the end of the study, the LDL serum level was measured. The result of One - Way Anova test showed LDL cholesterol serum levels of group rats with STZ induction and given $12.75 \mathrm{mg} / \mathrm{kg} \mathrm{BW}$ golden sea cucumber extracts $(\mathrm{x}=7.4 \mathrm{mg} / \mathrm{dl})$ significantly decreased $(\mathrm{p}=0.005)$ compared to LDL cholesterol levels of group rats which were only induced by STZ without given golden sea cucumber extracts $(\mathrm{x}=12.6 \mathrm{mg} / \mathrm{dl})$. This research showed that the administration $12,75 \mathrm{mg} / \mathrm{kg}$ BW of golden sea cucumber extracts for 21 days reduced serum LDL cholesterol levels because golden sea cucumber contains eicosapentaenoic acid (EPA) and docosahexaenoic acid (DHA) at work as antioxidants.
\end{abstract}

Keywords: LDL cholesterol, insulin resistance, Streptozotocin (STZ), stichopus hermani

\section{Introduction}

Diabetes Mellitus (DM) is a group of metabolic diseases characterized by hyperglycemia as a result of abnormalities in the secretion of the insulin, the action of the insulin, or both [1]. In experimental, DM is often caused by the administration of alloxan and streptozotocin (STZ), which can cause damage to pancreatic beta Langerhans cells [2]. STZ works by forming highly reactive free-radicals that can cause damage cell membranes, proteins, and deoxyribonucleic acid (DNA), thus causing disruption of insulin production by pancreatic beta Langerhans cells [2]. In the DM state, there is a decrease in insulin production, which causes impaired fat metabolism, namely the promotion

\section{How to cite:}

Setianingsih H, Putri FS, Mutiadesi WP, Yatmasari E (2020) The effect of golden sea cucumber (Stichopus hermanii) extracts to serum LDL cholesterol level as a result of insulin resistance. Indonesian Journal of Medical Sciences and Public Health 1 (1): 7 - 12. doi: 10.11594/ijmp.01.01.02 
of lipolysis that results in high levels of lowdensity lipoprotein (LDL) [3]. LDL molecule is small and dense, which circulates in the bloodstream and is atherogenic. These conditions can increase the risk of coronary heart disease (CHD), stroke, kidney failure, and other vascular diseases, thereby accelerating the risk of death [3].

Golden sea cucumber (Stichopus hermanii) has eicosapentaenoic acid (EPA) and docosahexaenoic acid (DHA) activities which are quite right to be used as a drug of superoxide dismutase which acts to prevent oxidative stress in hyperglycemic conditions so that golden sea cucumber is perfect to be used as a drug choice for DM [4].

Based on the various reasons above, research entitled the effect of golden sea cucumber extract (Stichopus hermanii) to serum LDL cholesterol level male Wistar rats (Rattus norvegicus) induced by streptozotocin.

\section{Material and Methods}

This research was experimental laboratory research. The research method used in this study is the posttest only control group design. This research conducted at the Embryology Laboratory of the Faculty of Veterinary Medicine, Airlangga University, Surabaya. All studies carried out in approximately three months, from August to October 2019.

The sample size used for each treatment group was determined using the Federer formula. The sample size for each group is five mice aged 2-3 months. Rats were acclimatized for seven days so that the rats could adapt to food and laboratory conditions. The rats were treated in a $40 \mathrm{~cm} \times 30 \mathrm{~cm} \times 20 \mathrm{~cm}$ cage with adequate ventilation at the top of the cage, and each pen contained five mice.

\section{The Production of Golden Sea Cucumber Ex- tracts}

Fresh golden sea cucumber weighing 9 kilograms was taken from Sumenep, Madura Island. Golden sea cucumber is cleaned, removed internally, and cut into $3-10 \mathrm{~cm}$ sizes and dried in an oven at $50{ }^{\circ} \mathrm{C}$ until dry. The dried golden sea cucumbers mashed with a blender into powder and obtained a weight of
$1.3 \mathrm{~kg}$. Golden sea cucumber powder was macerated by repeatedly stirring for 8 hours and soaked in $80 \%$ ethanol solution for 24 hours after which, $80 \%$ ethanol solution was collected, and gold sea cucumber pulp was mastered with $80 \%$ ethanol in the same way (total ethanol solution being used as much as 5.5 liters). The $80 \%$ ethanol solution obtained was evaporated with a water temperature of $50{ }^{\circ} \mathrm{C}$ until the ethanol solution evaporated and received a concentrated extract of 242.5 grams of golden sea cucumbers [5].

\section{Administration of STZ}

Hyperglycemia induction will be done by injecting STZ solution intraperitoneally at a dose of $40-50 \mathrm{mg} / \mathrm{kg} \mathrm{BW} \mathrm{[6].} \mathrm{STZ} \mathrm{calculations}$ for rats with an average body weight of 175 grams are:

- Doses of STZ in mice $=40 \mathrm{mg} / \mathrm{kgBW}$ and $50 \mathrm{mg} / \mathrm{kgBW}$

- 40 mg: 1000 grams $\times 175$ grams $=7$ $\mathrm{mg} / 175 \mathrm{~g}$ BW per injection.

- 50 mg: 1000 grams x 175 grams $=8.75$ $\mathrm{mg} / 175 \mathrm{gBW}$ per injection.

STZ was dissolved using citrate buffer $\mathrm{pH}$ 4.5 and then induced in intraperitoneal mice as much as $0.5 \mathrm{~mL}$ to each rat [5].

\section{Treatment Stage}

After acclimatization, rats that had been assigned as samples were randomly divided into five groups, and each group was put into their respective cages. The treatment of each group is as follows:

- Negative control (K-): Group of rats that were not induced by STZ.

- Positive control (K+): Group of rats induced by STZ at a dose of $40 \mathrm{mg} / \mathrm{kg} \mathrm{BW}$ on day eight, and on day 22, STZ was injected with a dose of $50 \mathrm{mg} / \mathrm{kg} \mathrm{BW}$ intraperitoneally.

- Treatment Group 1 (P1): Group of rats induced by STZ at a dose of $40 \mathrm{mg} / \mathrm{kg} \mathrm{BW}$ on day eight and on day 22 STZ was injected with a dose of $50 \mathrm{mg} / \mathrm{kg} \mathrm{BW}$ intraperitoneally, then this group was given a golden sea cucumber extract at 4.25 $\mathrm{mg} / \mathrm{kg}$ BW once every morning starting 
from the $26^{\text {th }}$ day to the $47^{\text {th }}$ day. The administration of golden sea cucumber extracts was done by an intragastric method using intragastric sonde.

- Treatment Group 2 (P2): Group of rats induced by STZ at a dose of $40 \mathrm{mg} / \mathrm{kg} \mathrm{BW}$ on day eight and on day 22 STZ was injected with a dose of $50 \mathrm{mg} / \mathrm{kg} \mathrm{BW}$ intraperitoneally, then this group was given a golden sea cucumber extract at 8.5 $\mathrm{mg} / \mathrm{kg}$ BW once every morning starting from the $26^{\text {th }}$ day to the $47^{\text {th }}$ day. The administration of golden sea cucumber extracts was done by the intragastric method using intragastric sonde.

- Treatment Group 3 (P3): Group of rats induced by STZ at a dose of $40 \mathrm{mg} / \mathrm{kg} \mathrm{BW}$ on day eight and on day 22 STZ was injected with a dose of $50 \mathrm{mg} / \mathrm{kg}$ BW intraperitoneally, then this group was given a golden sea cucumber extract at 12.75 $\mathrm{mg} / \mathrm{kg}$ BW once every morning starting from the $26^{\text {th }}$ day to the $47^{\text {th }}$ day. The administration of golden sea cucumber extracts was done by the intragastric method using intragastric sonde.

\section{Blood Sampling}

Rats fasted \pm 16 hours before blood was drawn. Blood pulled from the rat's heart through surgery. The blood was then collected in an Eppendorf tube of $\pm 2 \mathrm{~mL}$ per rats. Blood centrifuged at a speed of $3000 \mathrm{rpm}$ with a radius of $12 \mathrm{~cm}$ for 10 minutes. The serum obtained was stored at $-4{ }^{\circ} \mathrm{C}$ until the serum was used for the analysis of LDL cholesterol levels; this storage used to maintain the quality of the sample.

\section{Measurement of LDL Cholesterol Levels}

Determination of LDL cholesterol levels using the homogeneous enzymatic colorimetric test method with Cobasintegra 400/400 plus LDL-Cholesterol plus $2^{\text {nd }}$ generation. This method for measuring direct LDL cholesterol levels utilized the selective micellar solubilization of LDL cholesterol by non-ionic detergents and the interaction of sugar and lipoprotein components (VLDL and chylomicrons) [7].
When detergents were included in an enzymatic method to measure cholesterol (cholesterol esterase cholesterol oxidase coupling reaction), the relative reactivity of cholesterol in the lipoprotein fraction increases in the following order: HDL < chylomicron <VLDL <LDL. In the presence of $\mathrm{Mg++}$, the sugar component significantly reduces the enzymatic reaction from cholesterol measurements in VLDL and chylomicrons. The combination of the sugar component with detergent allowed selective analysis of LDL cholesterol in serum [7].

\section{Results and Discussion}

The results of measurements of serum LDL cholesterol levels of each group experimental can be seen in Figure 1.

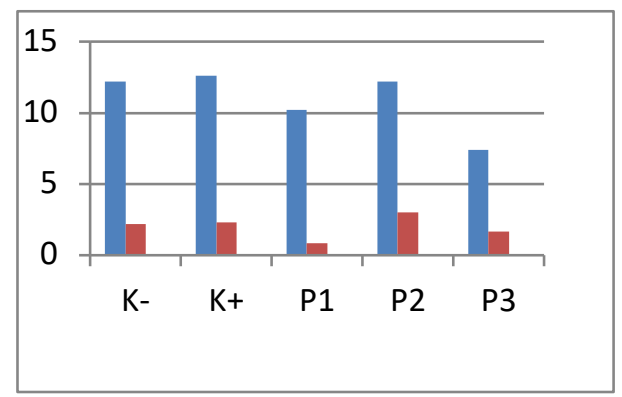

Figure 1. Mean and standard deviations of serum LDL cholesterol levels for each group.

\section{One Way Anova Test Results}

Based on the results of the One-Way ANOVA test, the significance value of $p=0.005$ $(p<0.05)$ was obtained, so there were significant differences in outcomes between the treatment groups. Therefore, it was necessary to proceed with the post hoc test.

\section{Post-Hoc Test Results}

Based on the Post Hoc analysis results with the Least Square Differences technique, the following results were obtained:

1. There was no significant difference in LDL cholesterol levels between the negative control group and the positive control group ( $\mathrm{p}$ $=0.770$ ).

2. There was no significant difference in LDL cholesterol levels between the negative control group and treatment group $1(\mathrm{p}=$ $0.153)$ and the treatment group $2(\mathrm{p}=$ $1,000)$. 
3. There was a significant difference in LDL cholesterol levels between the negative control group and treatment group $3(\mathrm{p}=$ 0.002 ).

4. There was no significant difference in LDL cholesterol levels between the positive control group and treatment group $1(\mathrm{p}=$ $0.090)$, with the treatment group $2(\mathrm{p}=$ 0.770 ).

5. There was a significant difference in LDL cholesterol levels between the positive control group and treatment group $3(\mathrm{p}=$ $0.001)$.

6. There was no significant difference in LDL cholesterol levels between treatment group 1 and treatment group $2(\mathrm{p}=0.153)$, and treatment group $3(\mathrm{p}=0.051)$.

7. There was a significant difference in LDL cholesterol levels between treatment group 2 and treatment group $3(\mathrm{p}=0.002)$.

The increase in mean LDL cholesterol levels in STZ induced white rats was caused by the action of STZ, which damaged pancreatic beta cells by forming highly reactive free radicals, namely ROS which can cause damage to cell membranes, proteins, and DNA [2]. According to Szkudelski in the Graham et al., [8] STZ could penetrate pancreatic beta cells through GLUT 2 and caused alkylation [2]. This occurs because of the similarity of the structure of STZ with glucose so that STZ can bind to GLUT 2.

When intracellular STZ metabolism occurs, nitric oxide was produced so that guanylyl cyclase activity increases and cGMP formation. STZ omitted worked by increasing xanthine oxidase in the mitochondria and inhibited the Crebs cycle. Oxygen consumption in the mitochondria became more limited. Production of adenosine triphosphate (ATP) decreased and caused a descent in the number of pancreatic beta-cell nucleotides [2].

An increase in LDL cholesterol levels occurred because in a state of extreme insulin deficiency could cause lipolysis of adipose tissue and released of free fatty acids and increased high activity on hormone-sensitive lipase in fat cells [9].

Increased activity of hormone-sensitive lipase caused hydrolysis of stored triglycerides, released large amounts of fatty acids, and glycerol into the blood circulation. As a result, plasma concentrations of free fatty acids increased within minutes. Free fatty acids then became the primary energy source for all body tissues besides the brain [9]. The energy obtained from the lipolysis process resulted from high levels of triglycerides [10].

Lipoprotein was needed to carry lipids because lipids were not water-soluble [11]. Increased triglyceride levels were also influenced by the presence of chylomicrons and VLDL lipoproteins. VLDL was converted into fatty acids and IDL by lipase enzymes, IDL could then be taken up by the liver through LDL receptors or converted to LDL [12]. Plasma LDL functions carried cholesterol and cholesterol esters to the liver and peripheral tissues [3]. Cholesteryl esters were lipids in foods that are hydrolyzed into cholesterol and then absorbed by the intestine along with other fats, then put into chylomicron lipoproteins together with cholesterol synthesized in the gut [11].

The average LDL cholesterol level in the STZ-induced rat group and gold sea cucumber extract dose of $4.25 \mathrm{mg} / \mathrm{kg} \mathrm{BW}$ (treatment 1) was $10.2 \mathrm{mg} / \mathrm{dl}$ when compared with the negative control group where the average LDL cholesterol level was $12.2 \mathrm{mg} / \mathrm{dl}$ or compared to the positive control group where LDL cholesterol level was $12.6 \mathrm{mg} / \mathrm{dl}$. There was a decrease in LDL cholesterol levels, although it was not too significant.

The average LDL cholesterol level in the STZ-induced rat group and the golden sea cucumber extract at a dose of $8.5 \mathrm{mg} / \mathrm{kg}$ BW (treatment 2) was $12.2 \mathrm{mg} / \mathrm{dl}$. Meanwhile, in the group of rats induced by STZ and extract of sea cucumbers, the dose of $12.75 \mathrm{mg} / \mathrm{kg} \mathrm{BW}$ (treatment 3) was $7.4 \mathrm{mg} / \mathrm{dl}$. Significant differences were seen between the treatment group 3 compared to the negative control group $(\mathrm{p}=$ $0.002)$, the positive control group ( $p=0.001)$, and the treatment group $2(\mathrm{p}=0.002)$.

This study showed that the administration of extracts of golden sea cucumbers (Stichopus hermanii) at a dose of $12.75 \mathrm{mg} / \mathrm{kg}$ BW per day for 21 days could reduce serum LDL cholesterol levels in Wistar-induced white male rats signif- 
icantly. Golden sea cucumbers acted anti-hyperlipidemic because they contain ingredients such as EPA-DHA, flavonoids, saponins, alkaloids, and tannins [13].

EPA-DHA in gold sea cucumber extract by $0.16 \%$ [13], if consumed in sufficient quantities, has the potential to reduce cholesterol in the blood. EPA-DHA was a natural fatty acid, including omega-3 [14], which could improve the circulation system and help prevent the narrowing and hardening of the arteries (atherosclerosis) and prevent clotting of blood vessels (thrombosis) [14]. EPA-DHA influences the mechanism of production of liver lipoprotein transport secreted into the blood [14]. Giving PUFAs, including omega-3s, could reduce cholesterol and LDL levels [16].

Flavonoids could lower blood glucose levels in people with Diabetes Mellitus [17], work by inhibiting the activity of the $\alpha$-glucosidase enzyme, interfering with the breakdown of maltose into glucose making it difficult to be absorbed by the intestine, or increasing tolerance to glucose and increased insulin secretion, as well as stimulated glucose uptake in peripheral tissues and regulated the number of enzymes involved in carbohydrate metabolic pathways [17].

Flavonoids, including fat-soluble non-enzymatic antioxidants [18], could stabilize ROS, where flavonoids reacted with reactive compounds from radicals so that radicals became inactive [17]. And could inhibit the activity of HMG-CoA reductase [17], caused a decrease in cholesterol synthesis and increased the number of LDL receptors contained in the liver cell membranes and extrahepatic tissue so that total cholesterol levels felt, with a reduction in cholesterol levels, LDL in the blood also reduced.

Saponins in golden sea cucumbers are glycosides that have an aglycone in the form of steroids and triterpenoids [19] including bioactive compounds that were useful as antidiabetic and antihyperlipidemic [20]. Saponins inhibited free radical activity by giving electrons, or hydrogen atoms inactivated free radicals also increased antioxidant enzymes such as SOD and catalase. SOD is an antioxidant enzyme that plays a role in catalyzing superoxide radicals $\left(\mathrm{O2}^{-}\right)$formed $\mathrm{H} 2 \mathrm{O} 2$ and oxygen molecules. If SOD and catalase increased, ROS regulation would also be increased, thereby reducing the risk of diabetes [20].

Saponins also play a role in increasing tyrosine phosphorylation from the insulin subunit $\beta$ receptor, inhibiting tyrosine phosphatase, and stimulating glucose transport activities, such as GLUT 4. Increasing the amount of GLUT 4 represents an improvement in the hyperglycemia state in DM [5]. Increased glucose transport into cells as a form of improving hyperglycemia in DM would reduce lipolysis and released free fatty acids in the blood circulation so that LDL cholesterol levels decreased [9].

In this study, if the results of the mean LDL cholesterol levels of rats in each treatment group were further analyzed, it was found in the P2 group the results of the mean LDL cholesterol levels were no different from the mean LDL cholesterol levels in the negative control group. Whereas in the $\mathrm{P} 1$ group, the mean LDL cholesterol level was $10.2 \mathrm{mg} / \mathrm{dl}$, and in the P3 group, the average LDL cholesterol level was $7.4 \mathrm{mg} / \mathrm{dl}$, indicating a significant decrease in LDL cholesterol levels compared to the negative control group.

Based on previous research, the administration of gold sea cucumber extract at a dose of $8.5 \mathrm{mg} / \mathrm{kg}$ BW in DM rats could increase the amount of GLUT 4, thereby improving the state of hyperglycemia in DM. The administration of a golden sea cucumber extract at a dose of 17 $\mathrm{mg} / \mathrm{kg} \mathrm{BW}$ also increased the amount of GLUT 4 , but not as well as a dose of $8.5 \mathrm{mg} / \mathrm{kg}$ BW [5]. Improved hyperglycemia by increasing glucose transport into cells, decreased lipolysis of adipose tissue and reduced the release of fatty acids and glycerol in the blood circulation [9]. Plasma LDL levels also decreased as a result of reduced cholesterol levels [3].

The mean LDL cholesterol level in the P2 group was inversely proportional to the theory and the mean LDL cholesterol level in groups P1 and P3. The P2 group reduced LDL cholesterol better than the P1 group but no better than the P3 group. Some possibilities that cause bias were, the error of the administration of extract of golden sea cucumber $8.5 \mathrm{mg} / \mathrm{dl}$ (in the 
treatment group 2) in this case related to human error, or an error occurred in the diagnostic tool to check LDL cholesterol levels.

\section{Conclusion}

Based on this research, it can be concluded that the administration of extract of golden sea cucumber (Stichopus hermanii) dose of 12.75 $\mathrm{mg} / \mathrm{kg} \mathrm{BW}$ of rats for 21 days can significantly reduce levels of LDL cholesterol in groups of experimental animals that are STZ induced. The administration of golden sea cucumber extract at a dose of $12.75 \mathrm{mg} / \mathrm{kg} \mathrm{BW}$ proved to be more effective in reducing serum LDL cholesterol levels significantly compared to the administration of gold sea cucumbers at a dose of 4.25 $\mathrm{mg} / \mathrm{kg} \mathrm{BW}$ or $8.5 \mathrm{mg} / \mathrm{kg} \mathrm{BW}$.

\section{Acknowledgment}

This work was financially supported by Hangtuah University. Therefore, we are grateful for this funding and support of this research.

\section{References}

1. DA (2014) 'Diagnosis and Classification of Diabetes Mellitus: Definition and description of diabetes mellitus. Diabetes Care. DOI: $10.2337 /$ dc14-S081.

2. Saputra, Suartha IN, Dharmayudha AAGO (2018) Agen Diabetagonik Streptozotocin untuk Membuat Tikus Putih Jantan Diabetes Mellitus. Buletin Veteriner Udayana 10(2): 116-121. doi: 10.24843/bulvet.2018.v10.i02.p0

3. Setyoadi, Utami YW, Yuliatun L, Sakina LF (2014) Broccoli Juice reduces levels of low-density blood lipoprotein in rats model of diabetes mellitus broccoli juice reduces blood lowdensity lipoprotein in diabetes mellitus mice model. Jurnal Kedokteran Brawijaya 28(1): 1-10.

4. Majdina, S, Mulawarmanti D, Rizki Y (2018) Effectiveness of Combination of Hyperbaric Oxygen Therapy and Golden Sea Cucumber Gel (Stichopus hermanii) on Increasing the Number of Osteoblasts in Diabetes Mellitus Mice Induced by Porphyromonas gingivalis Bacteria. DENTA 10(1):31-41. DOI: $10.30649 /$ denta.v10i1.30.

5. Safitri I, Purwanto B, ROchyani I, Prawobo GI, Sukmaya D (2019) 'Effect of Sticophus hermanii extract on fasting blood glucose and skeletal muscle glut 4 on type 2 diabetes mellitus rats model. IOP Conference Series: Earth and Environmental Science 217(1):1-5. DOI: 10.1088/1755$1315 / 217 / 1 / 012025$.

6. Damasceno D C et al. (2014) Streptozotocin-Induced Diabetes Models: Pathophysiological Mechanisms and Fetal
Outcomes,' BioMed Research International. Hindawi Publishing Corporation 2014: 1-11. DOI: $10.1155 / 2014 / 819065$.

7. Putra MDA (2013) Pemeriksaan Kolesterol LDL (LDL-C) Menggunakan Metode Homogen. Universitas Udayana, pp. $1-15$.

8. Graham ML, Jenecek JL, Kittredge JA, Hering BJ, Schuurman HJ (2011) 'The streptozotocin-induced diabetic nude mouse model: Differences between animals from different sources. Comparative Medicine 61(4): 356-360.

9. Guyton AC, Hall J E (2014) Buku Ajar Fisiologi Kedokteran, Elsevier, Singapore.

10. Wahyudi T, Widyastuti SK, Suarsana IN (2015) Profil Lipoprotein Plasma Tikus dalam Kondisi Hiperglikemia. Indonesia Medicus Veterinus 4(2): 116-121.

11. Murray RK et al. (2018) Harper's Illustrated Biochemistry (31st Edition), Biochemical Education.

12. Jonas A, Phillips MC (2008) Lipoprotein structure in Biochemistry of Lipids, Lipoproteins, and Membranes. Chapter 17. DOI: 10.1016/B978-044453219-0.50019-2.

13. Damaiyanti D (2018) Karakterisasi esktrak air teripang emas (Stichopus hermanii). Denta: Jurnal Kedokteran gigi 9(1): 19. doi: 10.30649/denta.v9i1.19.

14. Sukarsa DR (2004) Studi aktivitas asam lemak omega-3 ikan laut pada mencit sebagai model hewan percobaan (A Study of Activity of Omega -3 Fatty Acid of Some Marine Fish in Mice as the Experimental Animals), Omega, VII, pp. 68-79.

15. Rasyid A (2003) Asam Lemak Omega-3 Dari Minyak Ikan. Oseana XXVIII (3): 11-16.

16. Diana FM (2012) Omega3. Jurnal Kesehatan Masyarakat 6(2): 113-117.

17. Katzung BG et al. (2013) Farmakologi Dasar dan Klinik. Mc Graw Hill Education 2(12): 973-1007.

18. Winarsi H (2007) Antioksidan Alami dan Radikal Bebas. Yogyakarta, Kanisius.

19. Yanuartono et al. (2017) Saponins: Impacts on Livestock (Reviews) Saponins : Impact on Livestock ( A Review ) 6(2): 79-90.

20. Elekofehinti 00 et al. (2012) The Effect of Saponin from Solanum anguivi Lam. Fruit on Serum Lipid and Oxidative Stress in Hepatocyte of Diabetic Rats. Rev. Bras. Pl. Med. v 14(Suppl. 2012): 15-19. 